Volume 10 Issue 5

December 2019

\title{
Production, Development, and Environmental Policies: Paradoxical Landscapes in Colonia Aborigen Chaco (Ex-Aboriginal Reserve of Napalpí, Argentina)
}

Carlos Salamanca

Consejo Nacional de Investigaciones Científicas y Técnicas (CONICET), Argentina, salamanca.carlos@gmail.com 


\title{
Production, Development, and Environmental Policies: Paradoxical Landscapes in Colonia Aborigen Chaco (Ex-Aboriginal Reserve of Napalpí, Argentina)
}

\begin{abstract}
This article examines the experience of an Indigenous development plan carried out between 2005 and 2010 in Colonia Aborigen Chaco, an Indigenous settlement located in Chaco province, Argentina, originally established in 1911 as the Aboriginal Reserve of Napalpí. On the reserve, inhabitants were forced to settle down as the State appropriated their traditional territories. Here, I propose a critical analysis of this experience with ethnographic description pertaining to the long historical processes that inhabitants of Colonia Aborigen endured, which systematically subjected them to alimentary, educational, productive, and religious routines aimed at transforming them culturally. I intend to demonstrate that it is necessary to review a series of assumptions, which are quite prevalent in Indigenous policies, about what an Indigenous person, an Indigenous territory, and an Indigenous development are supposed to be. I emphatically assert that it is necessary to have a critical approach towards these historical processes of constitution in order to better understand Indigenous rights and development within Indigenous territories.
\end{abstract}

\section{Keywords}

development, Chaco, Qom, reserves, colonialism, environmentalism, Argentina

\section{Acknowledgments}

I am grateful to Omar Notagai, Emilio Notagai, Romualdo Salustiano, and Nieves José, and to every inhabitant from Colonia Aborigen. I thank Juan Almirón, Hugo Rorhmann, and Alejandro Ruberto for offering me information about Colonia Aborigen and its water issues. I am also grateful to Frank Paul and his family, who were my most frequent interlocutors in Resistencia during those years.

\section{Creative Commons License (ㄷ) (1) $\Theta \Theta$}

This work is licensed under a Creative Commons Attribution-Noncommercial-No Derivative Works 4.0 License. 


\section{Production, Development, and Environmental Policies: Paradoxical Landscapes in Colonia Aborigen Chaco (Ex-Aboriginal Reserve of Napalpí, Argentina)}

Over the past few decades, the Qom, ${ }^{1}$ Indigenous people of the Chaco region, ${ }^{2}$ have found that sanctioning the so-called Indigenist laws also provided an opportunity to be "acknowledged" in political and legal terms by countries such as Argentina that used to deny their inherent rights as the original inhabitants of the land. ${ }^{3}$ The amendment to the Constitución de la Nación Argentina (1994) included the official recognition of "the ethnic and cultural pre-existence of Indigenous Peoples of Argentina" and "the legal capacity of their communities, and the community possession and ownership of the lands they traditionally occupy” (Article 75.13). The Constitution also guaranteed to:

Regulate the granting of other lands adequate and sufficient for human development; none of them shall be sold, transmitted, or subjected to liens or attachments. To guarantee their participation in issues related to their natural resources and in other interests affecting them provinces may jointly exercise these powers. (Article 75.17)

In the provinces with territory in the Chaco region, there have been legal changes in similar terms in Formosa in 1991, Chaco Province in 1994, and Salta in 1998.

These laws have been taken, both by Indigenous Peoples and the broader national society, as an extraordinary, positive, and irreversible step toward establishing human rights for Indigenous Peoples. Nevertheless, this idea of a new, fresh, and novel relationship between Indigenous Peoples and Argentina hides a long-term history of interaction between Indigenous Peoples, the Argentine national community, and the Argentine State that is characterized by violence, segregation, stigma, and discriminationincluding long-term interactions with Indigenous land reserves that reveal a complex and contradictory set of public policies regarding Indigenous people in Argentina.

The current vision of public policy for Indigenous Peoples misunderstands and hides the cultural contradictions and ambiguities created through these long-term interactions with the State and settler populations. This article is based on my personal experience with Indigenous people from Colonia Aborigen Chaco in the Province of Chaco, which used to be the Reducción de Indios de NapalpíAboriginal Reserve of Napalpí. Between 2005 and 2010, I worked in Colonia to help develop the Plan de Desarrollo Indígena (PDI, Indigenous Development Plan), a plan for Aboriginal development. During

\footnotetext{
${ }^{1}$ In this article, I use the term Qom in place of Toba because the former has recently been reclaimed by the Qom. Toba is a pejorative ethnonym apparently accorded by the Guarani people before colonization and subsequently used by Spanish settlers, and then by the Argentine State and society. For similar reasons, I use Moqoit instead of Mocoví.

${ }^{2}$ Gran Chaco is a vast alluvial sedimentary plain of $600,000 \mathrm{~km}^{2}$ extending from the current territories of Argentina, Bolivia, and Paraguay. Most of the Aboriginal Peoples from Gran Chaco were nomadic or semi-nomadic and based their economies on hunting, fishing, and harvesting.

${ }^{3}$ According to the Instituto Nacional de Estadísticas y Censos (Instituto Nacional de Estadísticas y Censos [INDEC], 2012), $3.9 \%$ of the population in Chaco Province identifies as Indigenous, which is approximately 41,304 persons. Among those who identify as Indigenous, 74.5\% identify as Qom, 11.2\% identify as Wichí, and 9.4\% identify as Moqoit. In Formosa province, $6.1 \%$ of total population identifies as Indigenous, approximately 32,216 persons, of which $44.9 \%$ identify as Wichí, $38 \%$ as Qom, and $13.5 \%$ as Pilagá. Data show the difficult social conditions faced by the Indigenous population in Chaco. Regarding housing, for example, approximately $92 \%$ of Indigenous households live in "poor to deficient houses," which means insufficient in size with no access to drinking water and sewers.
} 
The International Indigenous Policy Journal, Vol. 10, Iss. 5

that time, I traveled to Colonia for one or two weeks every month. Between 2010 and 2017, I visited Colonia at least once a year.

The Indigenous Development Plan was part of the Proyecto de Saneamiento Hídrico y Ambiental de la Línea Tapenagá [Water and Environmental Sanitation Project of the Tapenagá Line], funded by World Bank and implemented by the Minister of Production for Chaco Province. The total budget of the project was ARS $\$ 1,500.000$ (approximately USD \$500.000). The Plan included the following components: (a) to supply drinking water through the construction of 37 wells, (b) to construct 6 water reservoirs for cattle and livestock, (c) to restore the community association's seat, (d) to construct a school in Cacica Dominga, (e) to create a health center at La Redonda School, (f) to create a bypass for sewage, and $(\mathrm{g})$ to repair $30 \mathrm{~km}$ of road.

Colonia Aborigen is approximately $200 \mathrm{~km}$ from Resistencia, the capital city of Chaco Province. It is mainly rural and its inhabitants would resort to administrative nomination to divide Colonia from west to east into three lots numbered 38,39 , and $40 .{ }^{4}$ La Central, located in Lot 38 , is a relatively consolidated residential center that also has a police station, a health center, a civil registry office, and two educational centers. Today, La Central has 1,400 inhabitants, while in the rest of the Colonia there are 2,000 inhabitants. Poverty in surrounding rural areas has forced some families to move to urban Indigenous neighborhoods in La Central, such as Machagai and Quitilipi.

When the Qom and the Moqoit people from Chaco say they intend "to take part" (tener participación), they are not usually referring to voting, having a voice in the public sphere, or being acknowledged as collective rights holders. In fact, emphasizing a more pragmatic dimension, they are usually referring to being part of a network of benefits distribution that is mainly built around governmental structures of social assistance that, in the context of the 2001 national economic crisis, became central for the already fragile economies of Indigenous Peoples in Chaco. ${ }^{5}$ Those structures allowed for the circulation of public aid in the form of food, money, and/or development projects starting at the beginning of the national crisis in 2001. The Indigenous people who could not participate in those distribution networks were not able to obtain benefits from those social assistance programs; therefore, they had to meet their basic needs through their own formal or informal work.

Protecting himself from Chaco's scorching summer sun, Nieves José told me, "It was the water that brought the change. Then we started to take part" (personal communication, 2010) ${ }^{6}$ At that time, Nieves was the Moqoit cacique (chief) at Cacica Dominga in Colonia. I inferred from this remark and other conversations that he was talking about the water wells that were dug as part of the PDI. Yet, José was not talking about the wells or the PDI. The "water" he was referring to was actually the flooding in the 1980s

\footnotetext{
${ }^{4}$ In the first stages of national colonization at the end of $19^{\text {th }}$ century, lands in Chaco region were divided and identified by consecutive numbers. This administrative nomenclature was used before the cadastral system implemented some decades later. In some regions, the numbers were incorporated into the naming of the territory.

${ }^{5}$ I often use the term Aboriginalbecause it is the term most frequently used to refer to Indigenous people in Argentina. The term Indigenous is commonly used in international, national, and provincial legislation; however, Aboriginal is predominately used in public discourse and Indigenous is rarely used in public debates.

${ }^{6} \mathrm{Almost}$ all Indigenous people in Colonia speak Spanish so all of the fieldwork in this article was carried out in that language. This article follows 4 years of fieldwork in other Chaco regions, which examined historical aspects and provided the basis for a comparative analysis between the people living in Colonia Aborigen and other Qom communities. This fieldwork and analysis were part of my doctoral dissertation, which I was preparing while working in Colonia.
} 
that forced him and his family, as well as those who lived near Burgos estuary in the Colonia lands, to abandon their houses after losing their properties to floodwater. The floods occurred between 1982 and 1983 in different zones of Chaco region, leaving some communities facing a critical emergency. In Colonia, the impact of the flooding was amplified by infrastructure built by the government during the last dictatorship. Risks, catastrophes, and vulnerability are not natural phenomena that are distributed randomly within populations or spatial-temporal contexts (Beck, 2007; Natenzon \& Ríos, 2015). Some people I interviewed remembered that some areas in Colonia remained flooded for several months; numerous Moqoit and Qom families lost their homes and all of their possessions and had to be evacuated. The relocation process involved an unusually intense relationship between Indigenous Peoples and authorities that was very different from the sporadic contact they used to have. Yet, referring to floods as the beginning of a relationship with the government or the State is inaccurate since Nieves himself, and the Moqoit people in general, had maintained political relationships with the government, both in the local and the regional contexts, for many years. Nevertheless, Nieves' comment reveals that the social and environmental links in Colonia Aborigen today were forged on the grounds of the triple inequity of benefits assignment, lack of political representation, and vulnerable domestic economies-on the one side were floods and droughts and on the other side was an economic crisis.

The remembrance of State violence, intertwined with daily structural poverty, a chronic need for water, the remains of violent colonial practices and spatial injustices, and a long-lasting "bureaucratic war"7 constituted the background of this experience working on a development plan, which can be placed amidst socio-environmental conflicts and the experience of Aboriginal development. Acknowledging the existence of several kinds of Indigenous political spaces (Biolsi, 2005), this article uses the case of Colonia to analyze reserves as specific Indigenous political spaces where Indigenous Peoples are inscribed into paradoxical landscapes where, on the one hand, they rarely find the possibility of selfdetermination and to make their own decisions regarding their territories and their own ways of living. On the other, they do not fit into the preconceived ideas about Indigenous Peoples established by the State. These false expectations and images can be explained by the excavation of history using cultural understandings, and the case of Colonia Aborigen Chaco (Ex-Reserve of Napalpí) will allow me to demonstrate it.

My analysis addresses two dimensions. The first dimension aims to contribute to ongoing debates about how to reshape the relationship between the State and Indigenous Peoples under neoliberalism. As Howard-Wagner, Bargh, and Altamirano-Jiménez (2018) have stated, neoliberalism is highly varied in its features, impacts, and outcomes. My conversations with the people of Colonia Aborigen indicate that their responses and reactions to neoliberalism are also varied. The second dimension of my analysis concerns time, memory, and history, as well as the future and projecting what will happen. In this dimension, I will show how contemporary people in Colonia see past State violence as a generative force for present action and mobilization. I will also show how ideas about the future well-being of Aboriginal Peoples, which are linked to historical experiences, are being shaped by the culture of the majority population, which may lead to the devaluation of certain traditional Indigenous practices - such as hunting and fishing, gathering food, using traditional medicines, or speaking Indigenous languages.

\footnotetext{
${ }^{7}$ In comparison with "ancient times," when the "ancient ones" were involved in armed conflicts and wars against "the Whites," contemporary Qom and Moqoit people use the expression "bureaucratic war"(guerra de papeles) today to talk about the ongoing conflict with the State and settler populations regarding Indigenous rights and, in a broader sense, the struggle for equality.
} 
The International Indigenous Policy Journal, Vol. 10, Iss. 5

In the first section, I analyze the historical processes by which reserves have been created and address how they evolved to constitute Aboriginal territories. I also consider how they set the scene in which social and environmental conflicts have taken place in Chaco, specifically regarding their role in enabling market and capital flow in the region. In the second section, I analyze these paradoxical landscapes through my ethnographic study of an infrastructure development project in Colonia Aborigen. Recognizing that development projects for Indigenous Peoples are conceived and designed under specific assumptions that originate outside of the community, this experience allows me to explain the limits of the conceptual apparatus regarding Indigenous rights.

\section{Socio-Historical Background}

As in other national border areas in Latin American, from the mid- $18^{\text {th }}$ century to the end of the $19^{\text {th }}$ century, Spanish colonial authorities first and then the Argentinean nation state imposed their economic political, and religious structures on the territory of Chaco, creating numerous difficulties for Indigenous Peoples (Gordillo, 2004; Iñigo Carrera, 1984; Salamanca, 2006). Military campaigns did not come to an end until late in the $19^{\text {th }}$ century with the proclamation in 1884 that the lands south of the Pilcomayo River belonged to the Argentine State, designating their Indigenous Peoples as subordinate to the State. In the context of the last military expeditions and, as part of the colonization strategy, the Aboriginal Reserve in Napalpí (in present day Chaco Province) was created by the national government in 1911 under the realm of the Comisión Honoraria del Ministerio del Interior (Ministry of Interior) and comprised an extension of eight square leagues (22,500 hectares).

Aboriginal Peoples from central Chaco, mainly the Qom and the Moqoit, were relocated to the reserve after being deprived of their lands by colonialization and military campaigns. North of the reserve, the Machagai and Quitilipi municipalities would be founded some years later along forestry areas and railway lines (Figure 1). Machagai and Quitilipi authorities and populations treated Indigenous people from Colonia as a disposable workforce for cotton production in the region.

Before colonization, social organization among the Qom and Moqoit people, who belong to the same Guaycurú linguistic family, was characterized by the existence of bilateral social units formed by the union of several extended families. Their members were inscribed in a "very tight net of alliances that included, by consanguinity or by alliance, all or almost all of their members" (Cordeu \& de los Ríos, 1982 , p. 163). These social units adapted to the rhythm of ecological cycles within relatively defined territories. Differences between the Qom and the Moqoit precede colonization and prevail because of the experiences they have faced and how they have dealt with them. Those differences also emerge in the local context of Colonia, in which the Qom and the Moqoit people have been forced to share a common territory with some negative consequences, especially for Moqoit, who are fewer in number than the Qom, and for several decades had more restricted access to benefits distribution networks. According to the law, local associations (formed by the inhabitants of each community) are the formal mechanism for political participation. In Colonia, the Qom and Moqoit people shared the same association ${ }^{8}$ until the 1990s when the Moqoit decided to form their own organization. According to testimony from the Moqoit in 2006, they perceived that the Qom in the Association were leaving them out of discussions and resource allocation decisions. After the 1990s, two organizations-not one-represented the interests of Indigenous peoples and their communities.

\footnotetext{
${ }^{8}$ For a comparable situation of forced coexistence in the United States, see Dippel (2014).
} 


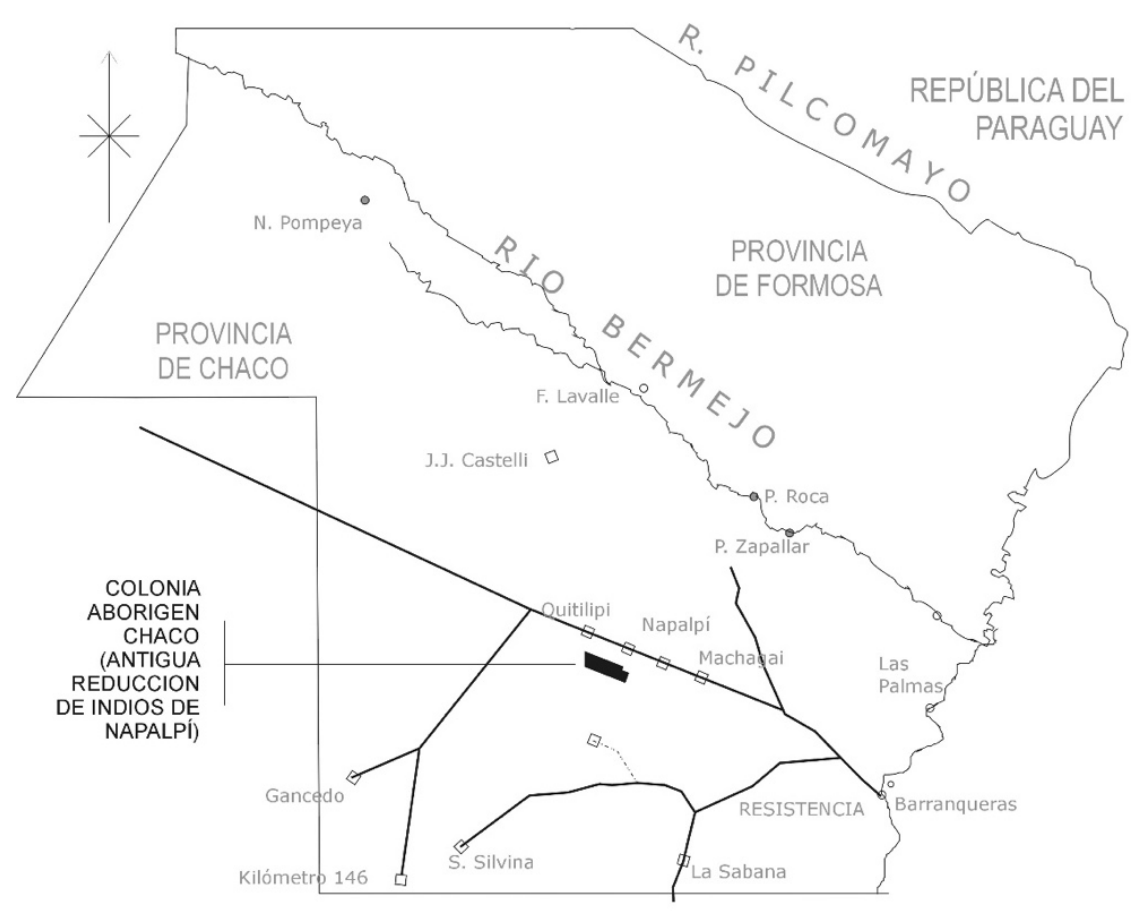

Figure 1. Location of Colonia Aborigen Chaco, ex-Aboriginal Reserve in Napalpí, in the regional context. Map by Author, 2012.

To reinforce the objective of territorial colonization, the reserve system was intended to lead a radical transformation among Aboriginal Peoples through agricultural work, Catholic evangelization, literacy, and permanent surveillance on the part of the reserve's authorities. The clearest disciplinary model proved to be altering the living conditions within Indigenous communities. Through different control mechanisms, Aboriginal people were forced to work harvesting cotton, not only on the lands they were assigned within the reserve but also on nearby tenant properties in return for meager wages. Until at least the mid- $20^{\text {th }}$ century, a person in charge of the administration of the reserve checked, one by one, the farms precariously assigned to the inhabitants of Colonia, giving tickets to be exchanged for goods in the administration office of the reserve in La Central. These tickets were given on the condition that the farms were well kept. Since the cotton harvest was a periodic activity, the Aboriginal people continued to voluntarily migrate seasonally in order to work in the sugarcane mills in the west where they were better paid (Gordillo, 2004).

Given that colonialism had relegated Aboriginal Peoples to the lowest position in the production chain and social class, they endured the most severe consequences of this system and led revolts and demonstrations to show that they rejected being exploited. In the second decade of the $20^{\text {th }}$ century, the need for labor on the cotton farms surrounding the reserve increased, and the cotton farm owners demanded that the government limit the departure of Aboriginal people from the reserve to the 
The International Indigenous Policy Journal, Vol. 10, Iss. 5

sugarcane mills in the west (Iñigo Carrera, 1984), promoting a forced sedentary lifestyle that would allow a broader exploitation of Indigenous Peoples. In 1920, massive demonstrations took place in Napalpí to protest inadequate wages and administrators prohibiting Aboriginal people from selling their labor outside of the reserve (Figure 2). In 1924, the Aboriginal people mobilized. Depending on the sourceAboriginal people's testimonies or the anthropological or historiographical literature- this mobilization has been defined as a strike, a messianic action, and Aboriginal rebellion (Salamanca, 2010). Despite these varying definitions, there is general agreement that these demonstrations caused fear and stirred up racial prejudice about the "indomitable and violent nature" of Aboriginal Peoples. This endeavor led to a brutal repression by the army, backed by the non-Aboriginal population. The Napalpí massacre meant death for a still unknown and unpublished number of Aboriginal people. Moreover, it meant a long and complex process in which Indigenous people have faced the memories of these experiences for decades while enduring institutional and public silence about it. During those years, many Indigenous Peoples found some relief in Christian evangelism, to which the people of the reserve as well as most of the Qom of central Chaco had converted by the 1940s (Ceriani Cernadas \& Citro, 2005; Salamanca, 2009).

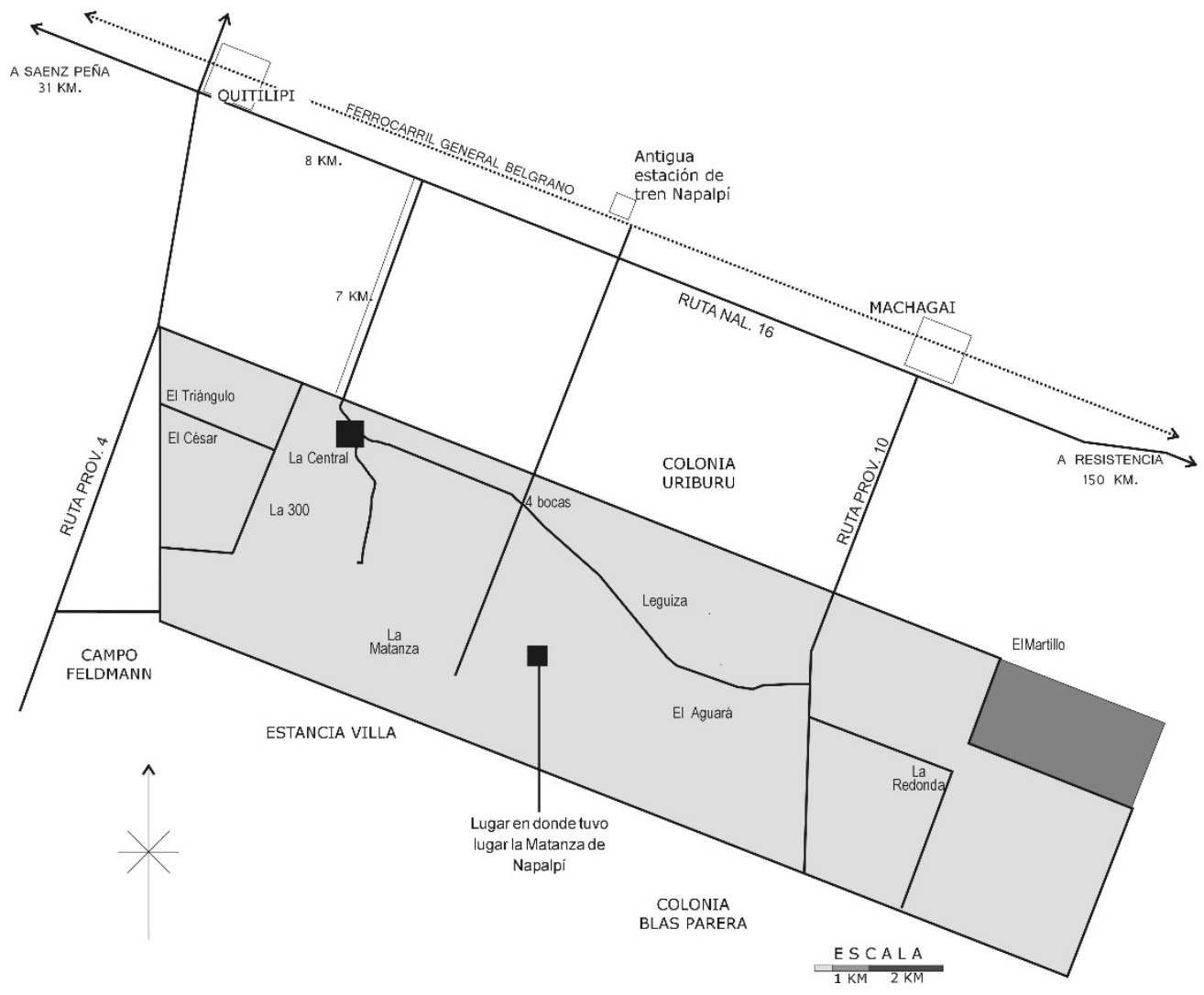

Figure 2. Colonia Aborigen Chaco, ex-Aboriginal reserve in Napalpí. Map by Author, 2012. 
In recent decades, the massacre has become a traumatic but foundational event with a complex meaning. In Napalpí, the massacre is understood as an episode that, because its traumatic nature, is constantly evoked by the Qom as a "generative force" for the present search for equality with the rest of the Argentine society. The massacre, as an event, is as much related to the present as it is related to the past, as it plays a role constituting Indigenous Peoples as a social group, both in terms of developing a relationship with non-Aboriginal groups generally and State representatives more specifically. In this, as I and other authors have noted (Bergholz, 2016; Peterson, 2007; Salamanca, 2015), there is a creative dimension of such violence: It brought about social links and helped create a "new world."

After the massacre, Aboriginal exploitation continued to take place for several decades. The producers neighboring the reserve took advantage of this situation because Aboriginal people had to turn to them in order to work. During this time, a regime was established by governmental authorities, and Colonia was perceived and utilized as lands of ambiguous legality, both Aboriginal land and land available for external intervention and labor exploitation. This concentration of Indigenous populations in a given territorial area, and outside the general colonization processes, was very different from the situation in the rest of Chaco region during the 1930s and the 1940s, in which the Qom acceded to some land in a scattered and fragmented manner.

During the 1950s, Aboriginal institutes emerged that were influenced by Indigenist discourses that had already arisen years before in other Latin American countries. These institutes respected and promoted some aspects of Aboriginal cultures as an ancient and remote component of national cultures. Although these had little influence in more secluded regions of Chaco, they had a significant impact in the Napalpí Reserve. This new view was accompanied by the 1957 creation of the Dirección Provincial del Aborigen (Aboriginal Provincial Office), the head office of which was in Napalpí.

De facto governments were in power in the 1950s and 1960s. The last military government (1976-1983) brought about big transformations in the spaces, realities, and identities of Chaco region (Salamanca, 2015). In Colonia Aborigen Chaco, lands were transferred to the inhabitants by means of a community property deed, and a civil association was created to facilitate agricultural production among its members. On the west side of Colonia, the military government built a pipeline carrying sewage from Quitilipi to the Indigenous lands in Lot 38 where there were some grazing areas and houses. During this period, the channels Bajo Hondo I and Bajo Hondo II were also built to cope with the floods by preferentially protecting the properties of big cotton growers in Sáenz Peña city. These transformations caused floods in the lowest areas of Colonia, as well as the west side, and led to the floods Nieves José was talking about at the beginning of this article. Years later, two groups of brick houses were built on the west side of Colonia; these would house some of the families displaced by the floods. Called Nueva Población and Cacica Dominga, they followed the urban neighborhood typology and did not respect the traditional pattern of scattered houses typical of Indigenous settlements.

A more active role in politics constituted a profound transformation for local and regional contexts. This transformation is similar to that of the power relations inside evangelical churches, where leaders started to be elected by vote and not by consensual agreements as was once done (Salamanca, 2006). From his early democratic experiences, Omar, a Qom in his 60s from Colonia, remembered how new voters were locked inside a barn and taken by truck to Quitilipi to vote. He remembered how fast the Indigenous 
The International Indigenous Policy Journal, Vol. 10, Iss. 5

people learned to participate in politics in Colonia, negotiating rewards with politicians in exchange for votes.

The 1994 Constitutional amendment acknowledged the ethnic and cultural pre-existence of Aboriginal Peoples in Argentina, and new laws promoted Aboriginal organizations. Participation by means of collective bodies, such as associations and communities, and individual figures, such as delegates, the cacique, and the president, were differently recognized and legitimated by the national and provincial governments. Nevertheless, in Colonia, where an Indigenous organization had already been recognized as an official civil association prior to those laws, the arrival of these new participatory figures was awkward. The new agenda to promote and enforce Indigenous rights could not be easily adapted to the structure, modalities of participation, and objectives of the existing association. The aim of this existing association was to support agricultural production in Colonia by making use of the political and economic capital derived from the Catholic Church or international cooperation that was relatively independent from traditional politics. Two Catholic non-governmental organizations (NGOs) actively contributed to the consolidation of this new political field: Equipo Nacional de Pastoral Aborigen (National Aboriginal Pastoral Team, ENDEPA) and Instituto de Desarrollo Social y Promocion Humana (Social Development and Human Promotion Institute, INDES). By training new leaders, who embedded ethnic claims into their demands, ENDEPA and INDES developed a particular leadership style that reconsidered the idea of politics - which was only available to political parties at that time. At the same time, they folded back and emphasized their own traditional forms of political action. These dynamics were deployed by ENDEPA and INDES mainly in the Lot 38 area through projects that included agricultural production, intercultural education, and housing.

In Colonia Aborigen and the rest of Chaco area, this broadening of the scope of politics, the active Aboriginal procurement and mobilization of resources, and the patronage through which political parties attempted to rule these new structures caused such a multiplication of participatory structures that it blurred the community principles on which this new field had been created. The government's idea that Aboriginal political agency is limited exclusively to "community issues" and through their community authorities has been contested. Numerous political alliances have been formed through which Aboriginal people participate in issues outside of their territories and through other political structures (some of them informal and flexible) besides local associations. However, certain alliances may threaten the unity of the community in Colonia Aborigen. Colonia had a number of political groups and factions that were based on kinship ties and other alliances between people from Colonia and other places. In a clear contradiction within this idealistic combination of agency and territory in Colonia, any individual could become a leader, and any group of relatives could become an association. For example, there emerged associations of farmers, artisans, and teachers that surpassed the scope and capacity of local associations. The leaders of these extended family associations gained political renown and the political landscape changed until it became a complex network of multiple leaders and multiple forms of political actionthemselves dynamic and changing — that sometimes led to conflict and tension (Figure 3).

DOI: https://doi.org/10.18584.iipj.2019.10.5.8584 


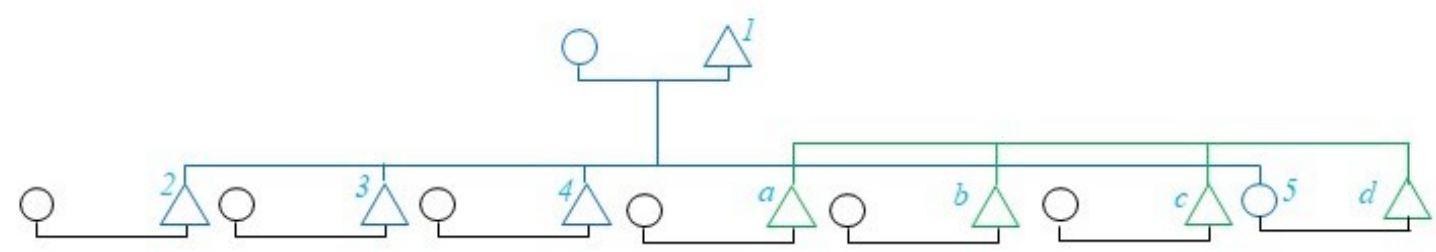

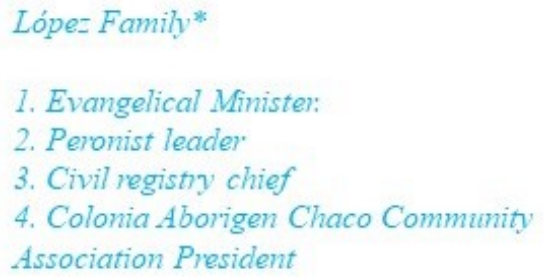

* Names have been changed to protect identiy of interviewed people.

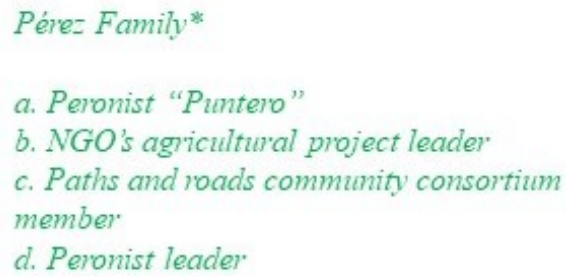

d. Peronist leader

Figure 3. The extended family and political associations based on a family from Colonia Aborigen Chaco. This kinship scheme shows the marriage of members from two Qom families of Colonia Aborigen. The marriage creates a kinship alliance that has high-level political influence and connects family members to different circles of political power. Drawn by Author.

Despite the autonomy granted by the Aboriginal legislation, traditional, non-Indigenous political parties took control of the Colonia Aborigen Association by advising members on administration and the performance of the necessary checks and balances to keep the association working. By assuming that these tasks could be the responsibility of the Association, which lacked both the technical knowledge and the administrative ability to do it, the project was not a participative mechanism but rather a rhetorical alternative to non-Indigenous politicians. During my fieldwork, it was common to find politicians from Machagai and Quitilipi attending meetings in punteros $^{\text {,9 }}$ houses, approving different lists of political participants and supporting candidates in their bids for election to the board of directors of the Colonia Association every two years.

For their part, NGOs working in Colonia supported collective participation in decision-making, validation of community decisions, respect for ethnic differences, and even for "rescuing" cultural roots. However, NGOs often alleged existing Aboriginal organizations were unable to carry out projects, stating that they were "tainted" by political patronage. Thus, each NGO systematically resorted to new mechanisms for ensuring community participation. When I arrived in Colonia in 2005, besides the classical structures of political patronage organized around the punteros' work, other networks were consolidated under the influence of NGOs that tended to produce similar relationships.

When the Aboriginal laws were passed, most of Colonia's inhabitants had already moved away from their traditional way of life as a result of historical experiences. Many found themselves far from their traditional language, the "Elders' habits," and the "food from the forest," instead becoming closer to the

\footnotetext{
${ }^{9}$ Community or neighborhood leaders who constitute the connecting node between political parties' patronage networks and the inhabitants in their home community or settlement.
} 
The International Indigenous Policy Journal, Vol. 10, Iss. 5

habits, language, and food of settlers. Yet, these changes did not mean that they did not recognize themselves as Indigenous Peoples. The more pragmatic dimension of their ethnic difference, however, was expressed as a set of considerations regarding traditional values, such as consensus-based decisionmaking, respect for Elders, hospitality, and generosity. These values were still held, but they mingled with other values, including a shift from collective benefit to personal benefit, democratic election of community leaders, and the emergence of new literate leaders who understood bureaucracy-especially in La Central. In practical terms, since the adoption of democracy, a few leaders from Colonia Aborigen had already gained some regional renown because they could speak Spanish and "knew White men's wit," so to speak. However, once the Aboriginal laws were sanctioned, these leaders became less relevant because they could not speak their language, overlooked their traditions, and pretended to look like White people, leading some to call them truchos (fake Aboriginal people). Aboriginal leaders from other areas who were closer to their traditional culture emerged to fill these roles. These kinds of Indigenous identity dilemmas are quite common around the world (see for example Hodgson, 2009). One of the political leaders from La Central called this "the trap of history." As we will see in the next section, what had happened at the subjective level had also occurred in the spatial dimension as inhabitants and territories confronted similar paradoxes.

\section{Plan for Aboriginal Development: Socio-Environmental Conflict and the Experience of Aboriginal Development}

\section{An (Un)fortunate Origin}

In 2002, based on an assessment of agricultural development and competitive insertion of products into the market, the provincial government embarked on the Proyecto de Saneamiento Hídrico y Ambiental de la Cuenca del Río Tapenagá (Water and Environmental Sanitation Project of the Tapenagá River Basin). ${ }^{10}$ This project, which dates back to the 1980 s, consisted of building a channel that allowed excess water from central Chaco to quickly run westward to the Paraná River in the rainy season. The project acknowledged the leading role of small and medium producers in carrying out policies to improve the soil's water retention through productive sustainable practices. Critics of the channel argued that it is a structural mistake to evacuate water in a region that is dry and prone to drought for half of the year (Figure 4).

In 2010, an official report recognized that the impact of the work "could not have been evaluated due to a prolonged drought" (Government of Argentina, 2010, p. 28). In 2018, a provincial technician concluded the severe, prolonged drought between 2002 and 2014 created conditions in which the "project work could not be maintained and in some places blockages had to be made to collect some water" (personal communication, Hugo Rorhmann, Director of Estudios Básicos APA, 2018).

\footnotetext{
${ }^{10}$ Known as the Programa de Servicios Agrícolas Provinciales (PROSAP) Saneamiento Hídrico y Desarrollo Productivo de la cuenca del río Tapenagá, this provincial agricultural program addressed water sanitation and productive development of Tapenagá River Basin. The total amount for the project was USD\$13,167,658 (Government of Argentina, 2010).
} 


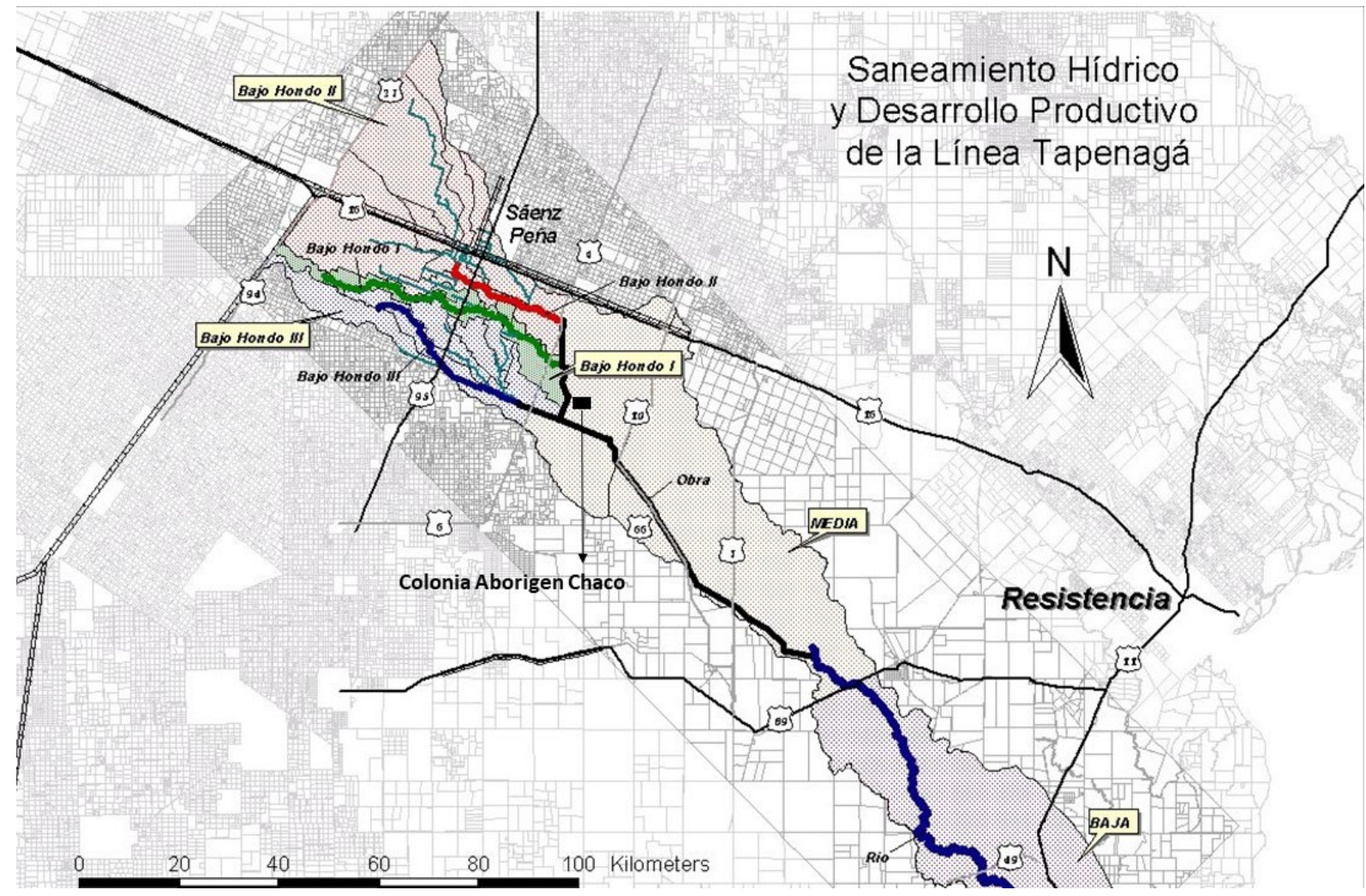

Figure 4. Tapenagá River Channel, regional placement. Drawn by Alejandro Ruberto (2015, published with permission).

The original tracing of the channel crossed the lands of Colonia Aborigen. According to testimonies from Indigenous people living in Lot 38 who were involved in the project's negotiations, government officers seemed to notice that Colonia was part of Indigenous Peoples' land and protected by law. Nevertheless, by the end of 2003, two backhoes attempted to enter from the west side of Colonia to continue constructing the channel on the lands of the community. The Qom and Moqoit people living nearby remembered how they opposed the trespassing: Backed by a Catholic Aboriginal NGO, they would stand in front of the machines and call the TV media. Tensions lasted for several days until provincial authorities agreed to negotiate with the Aboriginal people so as to comply with Aboriginal law and the World Bank Directives (2005a, 2005b) requiring free, prior, and informed consent from Aboriginal Peoples regarding every project granted by the World Bank that impacted Aboriginal Peoples.

An assessment made by a consultant team, hired by Chaco provincial authorities prior the public consultation (Rodríguez, 2004), considered the current living conditions of Colonia's inhabitants from a historical perspective that revealed longstanding discrimination. Among other things, they noted the lack of sewers and drinking water systems, few schools, deficient networks of roads, and a lack of government assistance for agricultural production. These issues were attributed to some of the dynamics already noted in the socio-historical background section of this article. As part of a participatory project, the team 
The International Indigenous Policy Journal, Vol. 10, Iss. 5

outlined an integral development plan, which included productive, organizational, and environmental aspects and emphasized the importance of Aboriginal culture. The team assumed that the plan would be a historic opportunity to establish more democratic and participatory relationships between Colonia's inhabitants and the government. The report also revealed how uncertain the inhabitants of Colonia Aborigen felt regarding both the usefulness and sustainability of the infrastructure project as well as its impact, given their recent negative experiences (Figure 5).

The inaugural act of this process, the public consultation held in March 2004, was an event of multidimensional and practical transformation. In the document that had been prepared by Rodríguez (2004), the socio-economic and cultural analysis became the Plan for Indigenous Development. Colonia's inhabitants were recognized as "Aboriginals" and collective political subjects, and Colonia was acknowledged as "Aboriginal territory." Surprisingly, the massacre of 1924 is mentioned frequently in the document, as if the Plan was linked to it as a sort of reparation act. Evoking those days, one of the inhabitants of El Triángulo in Lot 39, who I interviewed in 2006, stated, "It [the Plan] was about our sacred land. Sacred land because of what happened here [the massacre]." In practical terms, this sudden process of enshrinement meant two changes regarding land. The first change aimed to preserve the land; the second one aimed to repair it. First, the original trace of the channel was altered so that when it approached the west side of Colonia Aborigen, it would not cross the land but rather run parallel to the border and then continue east without entering Indigenous lands. Second, a purification filter was built, and pipelines were redirected so that sewage from Quitilipi would not pour into Colonia and would instead empty at the Tapenagá Channel, which borders the west side of Colonia (I will return to this topic later).

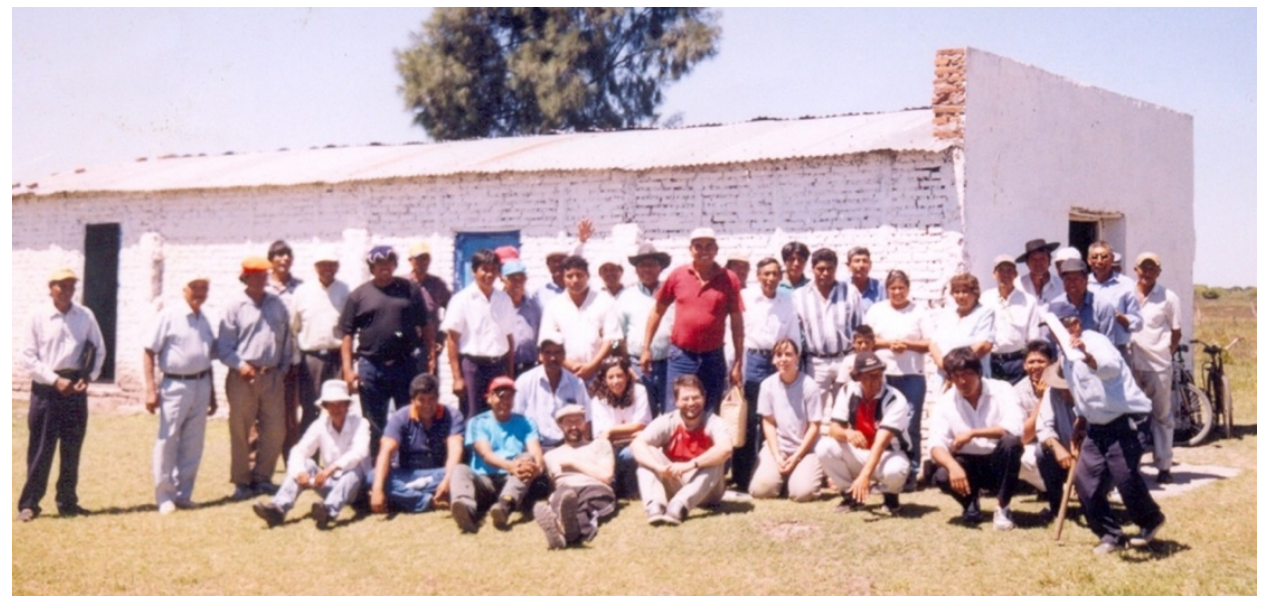

Figure 5. Inhabitants who took part in the environmental assessment process and the team of anthropologists who carried it out. El Salteño Church, Lot 38, Colonia Aborigen Chaco. Photograph by Emilio Notagai (2003, published with permission). 
For Aboriginal Peoples, the conflict and struggle that were the origin of this project revealed the effectiveness Aboriginal rights and reparation frameworks, as well as the role NGOs can play in enforcing these rights. For the government, however, this project meant that they could no longer rely on Aboriginal organizations, and NGOs were seen as being opportunistic and biased-"living off of the 'Indians'” and inducing them to rebellion. In Colonia, opinions were quite varied: While those who had participated in demonstrations and the consultation spoke of Aboriginal rights and looked forward to the Plan progressing, other Colonia inhabitants, such as those living in Lot 40 about $10 \mathrm{kms}$ away from the area of influence, were generally not aware of the Plan or did not concern themselves with it. This mutual mistrust between the Colonia Aborigen Indigenous people and the government prevailed for the following months. The election to determine the members of the consultant team experienced many difficulties and was delayed 10 months. Moreover, the consultant team that worked to understand the tensions in the context of historical and ongoing mistreatment did not take part in the implementation of the Plan.

By the time of my first visit to Colonia in 2005, Indigenous family economies had already begun to recover, mainly thanks to public monetary transfer programs. In the following years, in the context of the economic growth due to the expansion of soy production, some of those economies could be defined as "islands of poverty in a sea of wealth," to use Anderson and Parker's (2008) expression (p. 642). When I joined the consultation team in 2005, the Plan was already in the process of being passed, according to the construction drawings and budget estimates, before consultation with the Asociación Comunitaria (Community Association; Figure 6). At that time, the Project Implementation Unit (PIU) argued that they were facing major difficulties balancing beneficiaries' expectations with the limited amount of money allotted in the budget (approximately USD \$500,000). Although this amount was higher than the social investment habitually granted to Aboriginal communities, it was still insufficient according to local authorities.

Mistrust on the part of Aboriginal organizations was fuelled by both the considerable time required to establish work specifications and an erratic strategy by the PIU that consisted of delaying conflict, coopting some political leaders, and obtaining the approval to begin public works projects without disseminating information. Despite this tension, the PIU decided to keep working with Aboriginal organizations and NGOs during this period until the work began at the end of 2005.

As already mentioned, the Plan encompassed a wide range of projects, including drinking water and sewage infrastructure, restoring the community association seat, constructing a school in Cacica Dominga, constructing a health center in La Redonda School, and restoring $30 \mathrm{~km}$ of roads. Those who were part of the PIU (other professionals, specialists in agricultural production, and me) were excluded from participating in all decision-making processes by a coordinator, which we believed allowed the person to maintain patronage relationships with some association members. For some members of the community, it seemed that we were government employees - accomplices even - and, in some cases, technicians with good but irrelevant intentions. 


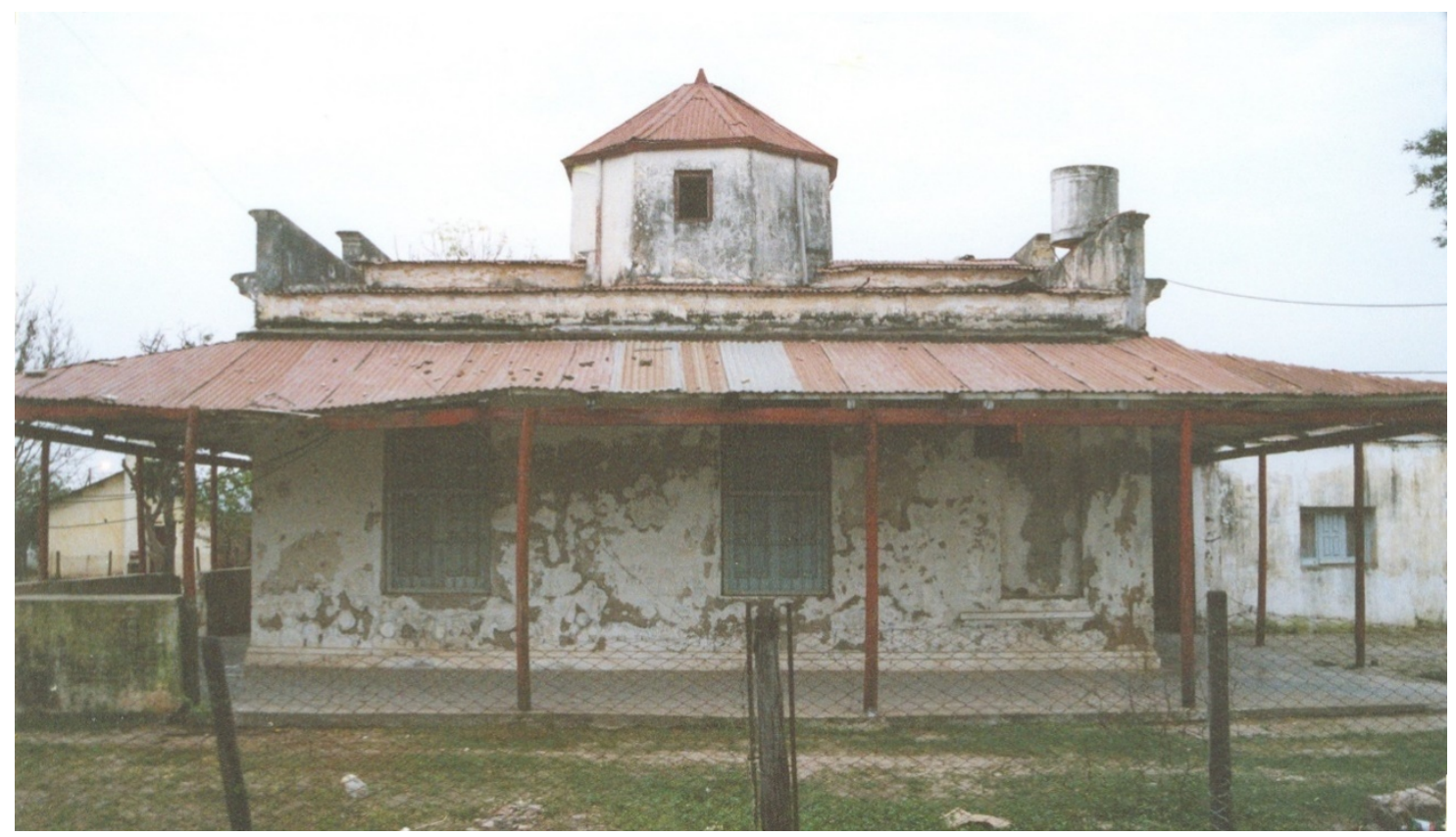

\section{Figure 6. Dirección del Instituto del Aborigen Chaqueño (Chaco Aboriginal Institute Office) in La} Central, Colonia Aborigen Chaco. Photo by Author, 2010.

During those tense months, more than the infrastructure projects or the participatory methods, the main source of conflict was around Indigenous Peoples' rights as neither side was well informed about the rights enshrined in the Constitution. The PIU coordinator, some of our partners, the auditors, and the technical personnel (who typically lacked experience working with Aboriginal groups and communities) questioned whether Aboriginal rights claims were legitimate or whether they were part of a strategy of ethnic opportunism. For their part, members of the community, with some exceptions, did not publicly support an Aboriginal rights approach, and some who claimed rights in public admitted in private that they did not have detailed knowledge about those rights. Given this context in which people had their own interpretation of what the term Aboriginal rights meant and in the face of difficulties following up on the implementation of the Plan for Aboriginal Development, I suggested we create more formal meetings to discuss Aboriginal rights. These meetings were called "trainings." Some of them were intended for the PIU members, including the coordinator; others were intended for organizations in Colonia. At first, these meetings were flatly rejected, and instead they became informal talks. Another set of training sessions, however, operated differently and will be discussed later in this article.

\section{Implementation Through Private Companies}

In order to implement the infrastructure projects, the PIU privileged private companies, arguing that it was following the World Bank operation policy. This principle excluded not only government offices but also Indigenous organizations within Colonia that were actually in a position to carry out such work. By relinquishing responsibility for implementation to private companies and their profit-based motives, the State retained little involvement in the participatory procedures and the organizational aspects of the Plan. Moreover, Indigenous people participated in the projects in accordance with the companies' 
criteria. For example, the companies hired workers informally, so they imposed this criterion in the implementation of the Plan. During the first days of work, Aboriginal people were forced to work 12 hours a day with no medical insurance. In a few cases, when the companies' engineers visited Colonia, they did not interact with the inhabitants; one even left and accused the Indigenous workers of being disrespectful because they spoke in their own language.

Nevertheless, the PIU also established direct contracting with the companies that were already building the channel and without soliciting tenders or public sector bidding. These companies lacked experience in projects with a social component. Before beginning the work, these companies made a number of changes to the projects, arguing that technical adjustments were needed, which in all cases resulted in additional profit for themselves. The irregularities were pointed out by the community, NGOs, and by two members of the consultant team, and these concerns were taken to the project's technical authorities first, then to provincial political authorities, and eventually to the World Bank. When I informally interviewed an employee from the World Bank in Buenos Aires in 2007, he recognized the weaknesses of the direct contracting model. However, he stated that there was a fear that corruption in public offices could put the implementation of projects at risk, so the direct contracting model was preferred.

The approach of the start date for the initial phase of the project, which had been delayed, caused some tensions to emerge in Colonia. The Asociación Comunitaria had been eroded due to its limited capacity to manage the projects and a decline in agricultural activities, which had been the reason for its creation four decades ago. But above all, the Association had become a powerful arena through which patronage relations, favors, and agreements were negotiated and contested, and where rumors, accusations, and gossip circulated. Within two months of beginning work on the projects, the Aboriginal organizations made the decision to stop the Plan implementation. They called for a follow-up meeting with the Indigenous organizations, the NGOs, and the PIU, and threaten to take the conflict to court.

The work stoppage lasted for three months and, in that time, mistrust grew in the community. At the same time, the PIU refused to hand in the necessary documentation by arguing it "did not possess any," but it could not explain how the projects were initiated without the necessary approvals. These tensions led the NGOs that worked in Colonia Aborigen to become the guardians of Indigenous rights against the government office that came to be seen by many as an enemy. Although the participation of NGOs was important, this change was made based on the Indigenous Peoples' increased opposition to the State. The NGOs saw themselves as being responsible for ensuring that the projects introduced by the PIU met the requirements of the community, leaving the government out of this process. This situation resulted in the PIU coordinator's resignation and a complete reconsideration of the Plan. The process changed significantly when a new coordinator assumed leadership: The community was given documentation about the work projects and other decisions were made that fit with the community's priorities, including the incorporation of an Aboriginal communicator, the mobilization of resources to carry out training, the monitoring of work projects, and a commitment to hold a follow-up meeting.

\section{Implementing the Plan and Dealing with Development Projects}

With the restart of the plan, however, Indigenous organizations and the NGOs realized that they lacked the technical capacity to monitor the documentation they had been given, such as project plans and budgets. The follow-up meeting, although called for by the PIU, never reunited all the actors. 
The International Indigenous Policy Journal, Vol. 10, Iss. 5

Meanwhile, members of Indigenous organizations individually devoted their time and effort to managing the project implementation, but information about the process was not communicated to community members who were not directly involved in those organizations. Members of the Association felt that the Plan was being allocated among the Lots (e.g., the number of wells or reservoirs each would get) without accounting for the real needs of each. The result was a fragmentation of the Plan, which we from PIU tried to prevent by making information about the consultation meetings public on La Central radio. Some members of the Association saw the training on Aboriginal rights, which was my responsibility to deliver, as a government strategy to distract them from the implementation of the projects that at the time were traversing numerous problems and difficulties.

The location of the projects carried out in the framework of the Plan should have been decided by the members of the organizations. However, it was not feasible to incorporate all of the inhabitants' demands. For example, some suggested that the beneficiaries of the projects should be the members who were on the payroll of the Association, rather than all of Colonia's inhabitants. These conflicts opened the door to leaders who were not members of the local association board (like punteros of the political parties, NGOs collaborators, and leaders of evangelical churches). The problem with this broadened participation was that it was mainly focused on personal interest in the location of the project's wells and reservoirs.

These discussions coincided with a chronic water shortage, which was a critical issue for all of the Chaco region (Figure 7). ${ }^{11}$ During the meetings in which the location of the wells was discussed, the Association members' personal interests became evident. Some wanted the wells located in places that benefited them personally; others wanted the wells placed near existing wells on lands that were rented to nonAboriginal producers; others wanted to place them in strategic places for their animals' needs, regardless of whether their neighbors had water. One member wanted to place a well on the land of a third party in exchange for money.

In the public meetings about the location of the wells, people external to the Association tried to prevent the wells and reservoirs from being placed based on individuals' preferences. However, some of the families who needed water the most were not able to make their case because they did not have the means to participate in the decision-making process or lived far away from La Central, where the meetings were held, and did not have the resources to get there. In order to create a territorially balanced distribution, we drew a locator map and allocated resources to places where most of the inhabitants' basic needs were met. During the process, which was full of twists and turns, threats of legal action, and conflict, we finally managed to draw up a consensual proposal with input from most of the stakeholders.

\footnotetext{
${ }^{11}$ For a similar case in Canada, see White, Murphy, and Spence (2012).
} 


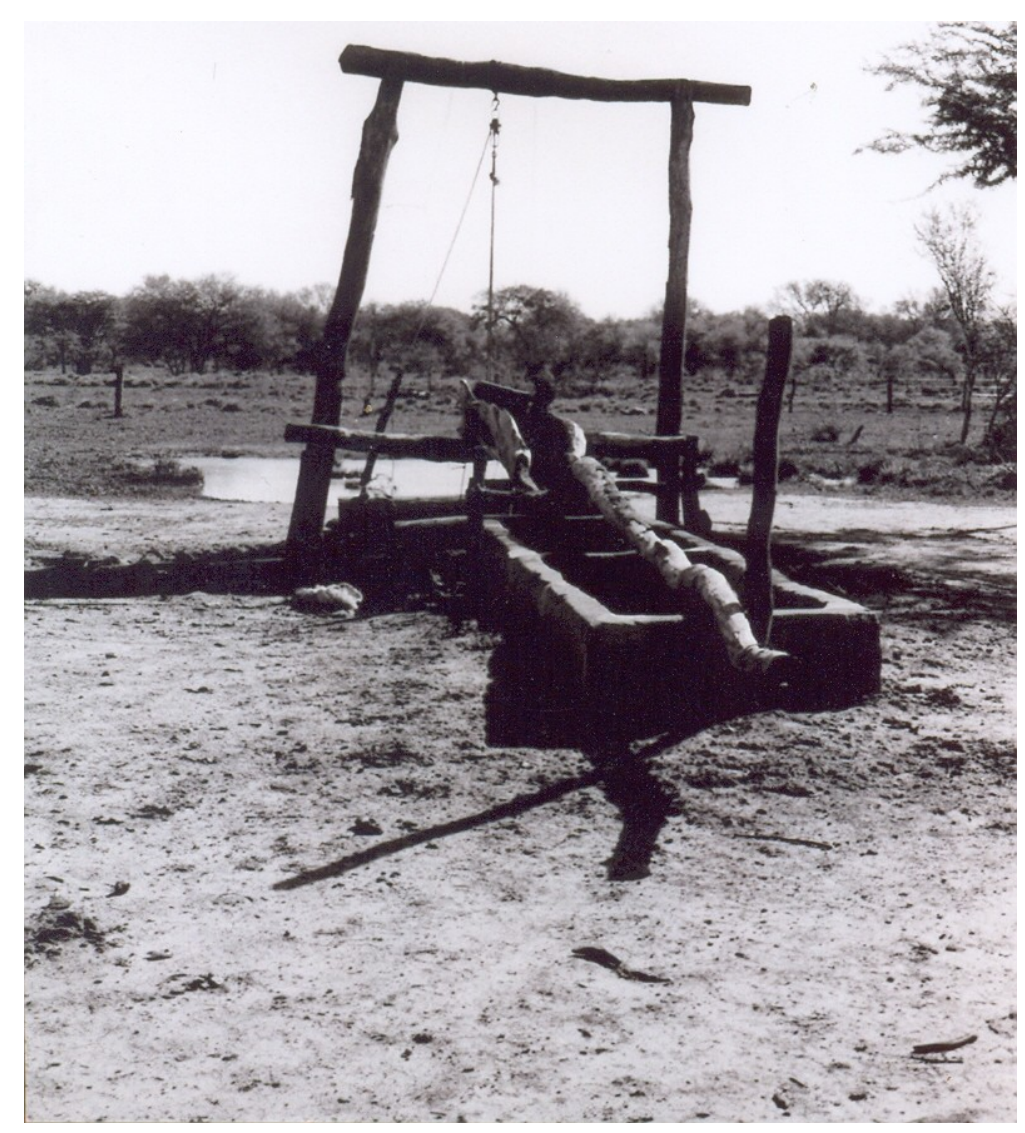

\section{Figure 7. Well drilled by community inhabitants from Lot 39. Some of these old wells were operational during the dry season. Photo by Author, 2006.}

\section{Territorial Knowledge vs. Technical Science}

During those days, we also discussed who would oversee the placement of the wells: the government technicians, who possessed technical knowledge, or the Elders from each area, who possessed territorial knowledge. As part of the PIU, I tried to establish an integrated view of the water issue in Colonia and ensure that the knowledge the inhabitants from Colonia had about their lands prevailed over technical criteria; in this process, my experience with two previous water supply projects in Colonia led me to believe that technical knowledge was unreliable. In Nueva Población, for example, a water supply network built less than two decades before had never worked, as technicians "misidentified" the location of the water feed source. Consequently, although the inhabitants had new houses, they kept supplying themselves with water from homemade wells and a reservoir supplied by a tanker from Quitilipi. Members of the Indigenous community saw the new network as being useless; it was widely seen as a proof of the arrogance of technical knowledge and the disregard for the Aboriginal knowledge about the territory.

Based on this traditional knowledge, I drew up alternative maps highlighting the places where water was available, the first one that had been made according to people's needs. I drew those maps with the help 
The International Indigenous Policy Journal, Vol. 10, Iss. 5

of the Aboriginal communicator and some people from Colonia by collecting testimonials from those whose grandparents or older relatives had advised about the best places to look for water (Figure 8).

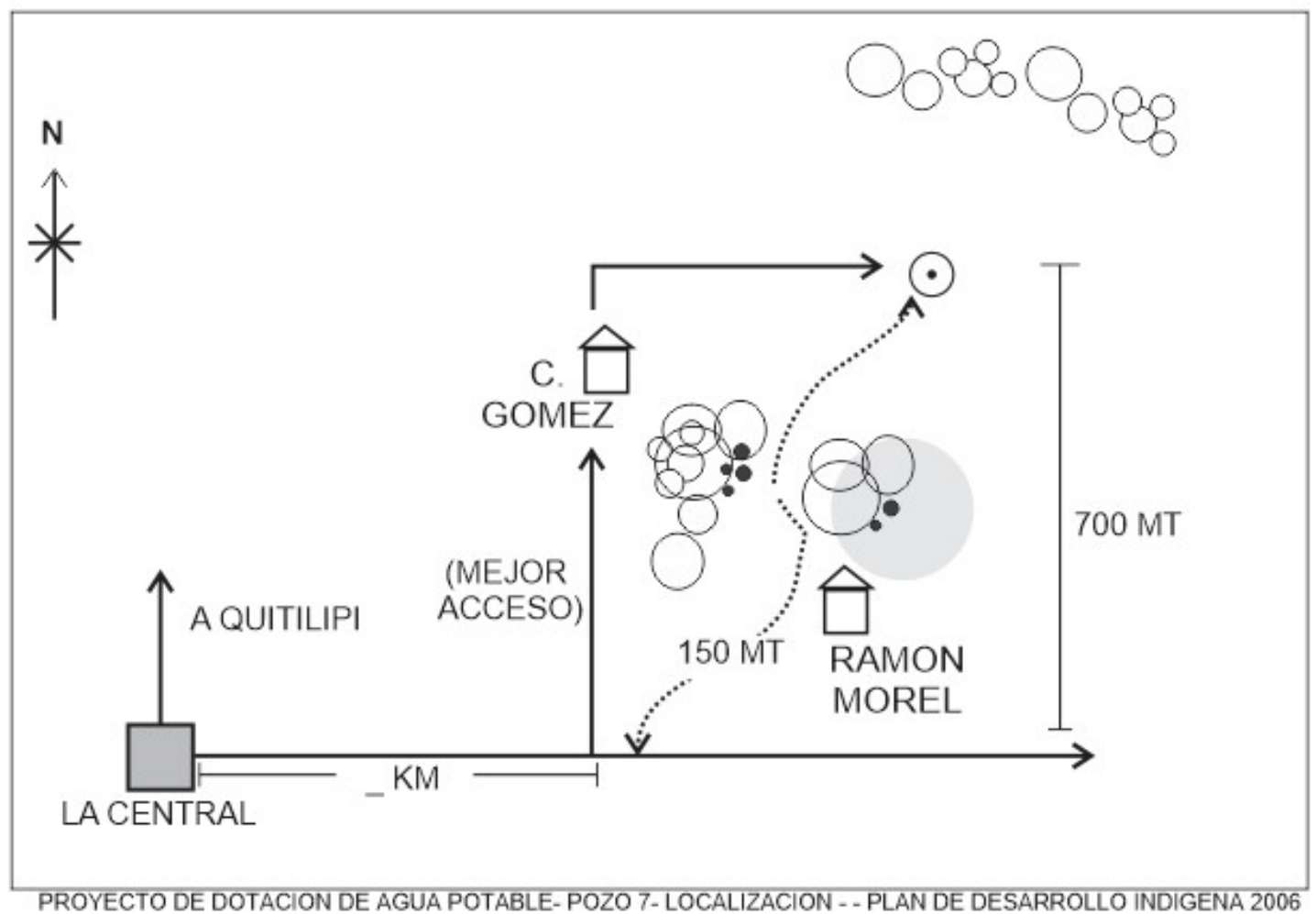

Figure 8. The location of some of the wells in Colonia Aborigen Chaco. Drawn by Author.

When work began, so did new difficulties. Some workers from the companies hired to build the wells had a skeptical attitude toward Aboriginal knowledge, which led to wells being hastily built in the places suggested by Aboriginal members without testing for water quantity or quality. When the implementation of the Plan was jeopardized by accusations of corruption by the NGOs and Aboriginal people, the PIU pushed the companies to commit to constructing the 37 wells; the companies agreed but removed the previous well drillings from their contractual obligations in order to reduce their costs. Moreover, instead of drilling the wells to the agreed depth, the companies drilled shallow wells, arguing the change was necessary due to technical issues. In addition, they hired non-Aboriginal personnel, stating informally to the director of PIU that Colonia's inhabitants were "too problematic." Therefore, in Colonia, inhabitants were seen as being "fake Indigenous people" when debating their rights and "typically Indigenous people" when they resisted or challenged the status quo.

When the work projects ended, almost half of the 37 water wells were not to the agreed depth and in 7 the water level dropped after three months until they dried up a year after they had been drilled. Others had a very slow recovery after the dry season, and the water was unfit for human consumption in at least 2 wells. Those who had opposed the Plan accused those who had set the sites for drilling of being ignorant. Those who were accused argued that the technicians were to blame because they continued with the work without conducting the necessary technical tests. Apart from the accusations and the 
economic profits that were at stake, these mistakes were contributing to environmental degradation, which neither technical nor empirical knowledge would offer any immediate solution.

\section{Environmental Threats in Segmented and Common Territories}

To conclude, let us go back to the project for sewage diversion (Figure 9). From June to November of 2005, there were many notifications, along with changing budgets and quotes, exchanged between the construction companies and the PIU. None of the inhabitants from Colonia participated in these very complex technical exchanges. Finally, a resolution, which was apparently adopted by government officials and the private company that was doing the work, ordered the pipeline to be diverted without consultation with the Aboriginal inhabitants. Moreover, although a filter was actually built, for technical reasons, it caused a substantial change in water quality. Even worse, when the government decided the sewage would go straight to the Tapenaga Channel, the foul odors and the threat of illnesses did not remain in a single area but extended along the west border of Colonia, an area where many Aboriginal people settled after the flooding in the 1980s. I met the members of the Association and some local leaders several times to discuss these issues. Many of the members of the Association had reported the problems to government officials and this situation has not been resolved to date (Figure 10).

The impact of the construction of the channel on Colonia's hydrologic system has never been discussed among Aboriginal inhabitants and the PIU. Many inhabitants from Lot 38 were worried about the control of water flux among the existing artificial and natural channels, as well as the new Tapenagá Channel. Their concern was reasonable, given that they had been affected by the previously drilled artificial channels. It was also that they, and not the NGO, had the knowledge required to assess the project. On a visit to Colonia in 2019, I found that the inhabitants' concerns were justified. After almost a decade of drought, the unexpected return of the rainy season caused the channel and the surrounding Indigenous lands to flood. The provincial government rapidly solved the problem by activating a plan to clean up the channel in order to allow the water to circulate; nevertheless, those who lived on these lands were uneasy about the threat of flooding over the following months.

In light of these problems and difficulties, and based on the research we had already begun in other projects, we drew a more complete map of Colonia that included not only the infrastructure built as part of the Plan but also the road networks, natural resources, and community infrastructure, such as churches and community rooms. With this map, we deliberately invoked a common history by detailing the history of the community using archival documents, photographs, biographies, and interviews. Such an approach, we thought, would offer an interactive perspective on the contexts and surroundings in which Colonia's inhabitants live and their life experiences. This process was different from typical mapping, which is undertaken from a general and abstract point of view. The challenges faced by the Aboriginal organizations in their interactions with the Argentine State were also embedded in the everyday challenges faced by the inhabitants of Colonia. The process of creating this map has been a powerful participatory tool that has enabled discussions about living conditions and current environmental challenges (Figure 11). 
The International Indigenous Policy Journal, Vol. 10, Iss. 5

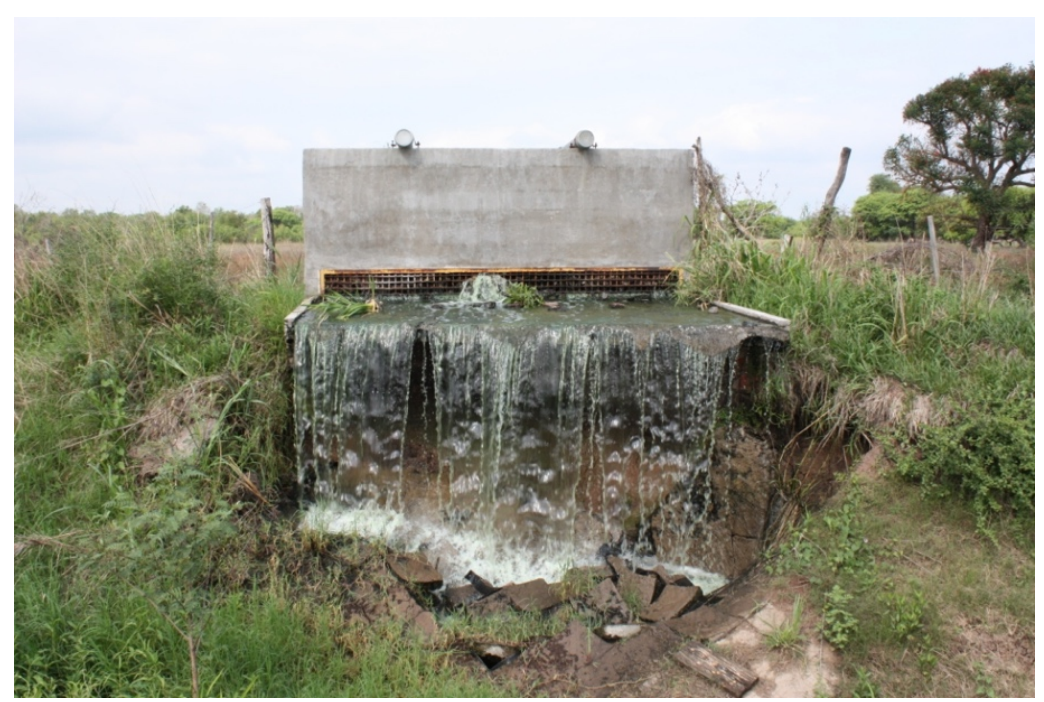

Figure 9. Ecological filter built to repair the environmental damage in Colonia Aborigen Chaco caused by sewage diversion from the neighboring population of Quitilipi. Photo by Author, 2010.

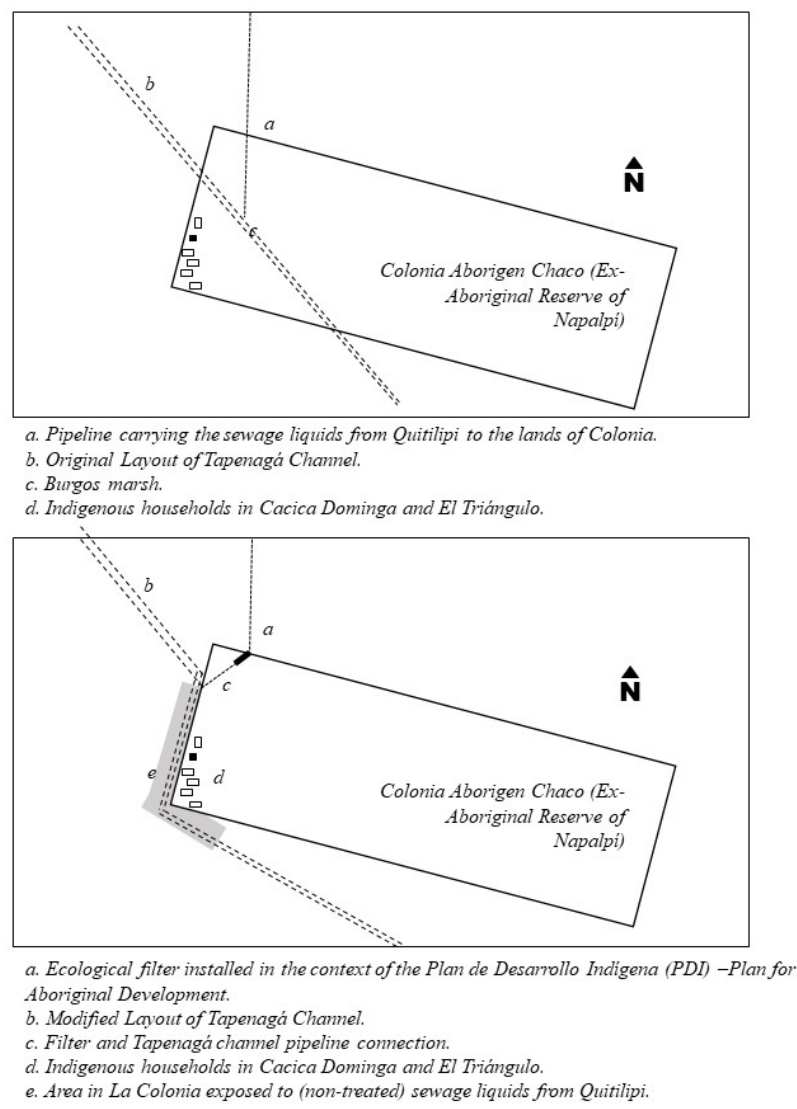

Figure 10. The threat of illness from sewage diversion from the neighboring community of Quitilipi into the Channel Tapenagá along the west border of Colonia Aborigen Chaco. Drawn by Author, 2010. 


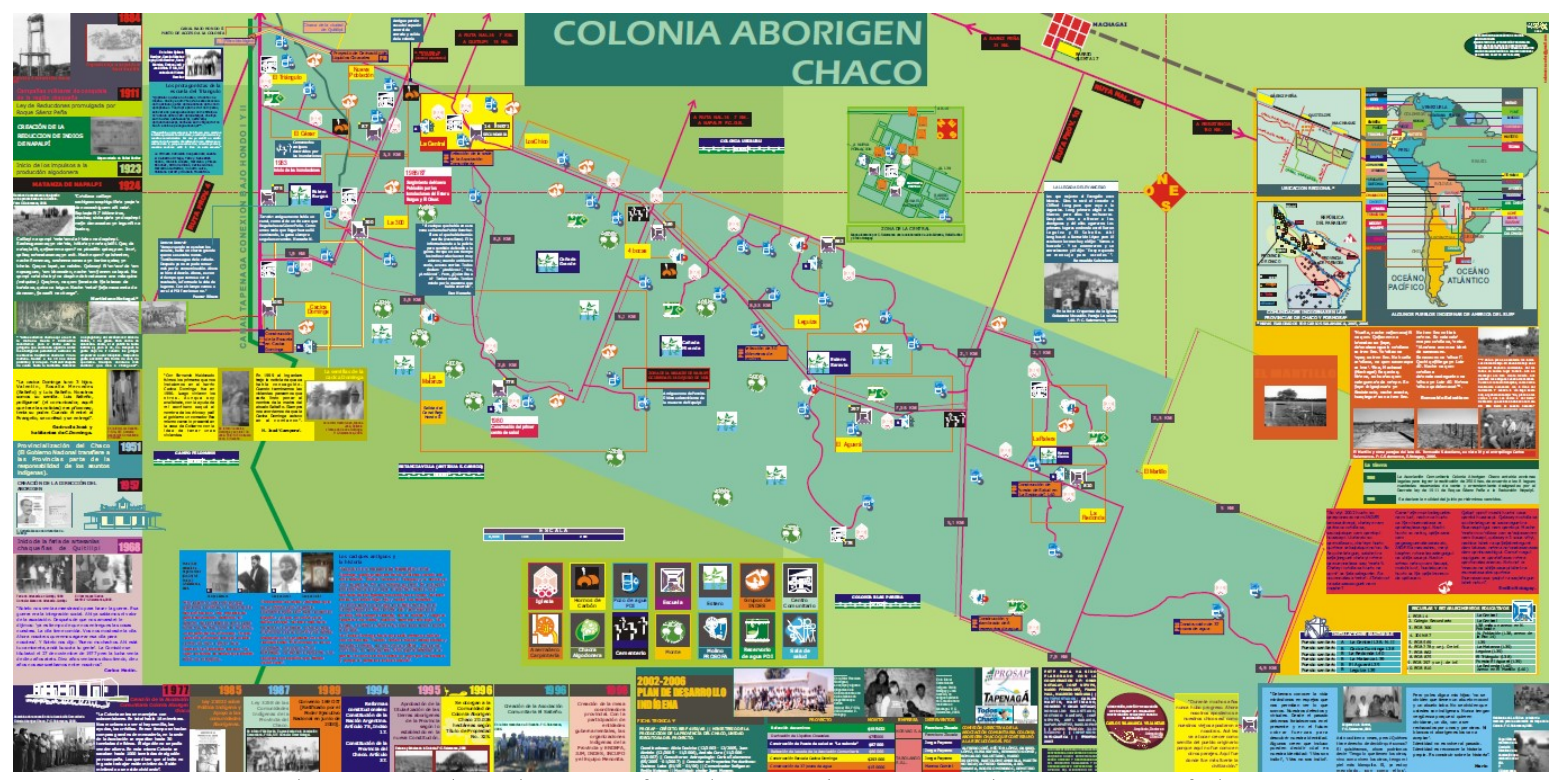

Figure 11. Historical-geographical map of Colonia Aborigen Chaco, part of the project Línea Tapenagá. Map by Author, 2007 ( $2 \mathrm{~m} \times 1 \mathrm{~m})$.

\section{Final Remarks}

In this article, I have analyzed an Indigenous development project from the detailed anthropological observation of political interactions in an Indigenous territory, founded as an Indigenous reserve at the beginning of $20^{\text {th }}$ century. Centered on the long-term experiences of the inhabitants from this territory, we have seen how production, development, and environmental policies overlap in the territory. Since each of these models has a specific territorial expression, the overlap produces a set of paradoxical landscapes that today constitute the social and material landscape where policies of Indigenous recognition and Indigenous development projects occurred and continue to take place.

Not all Indigenous populations are related in the same way to policies of recognition and, in that diversity, the experiences of the Indigenous people from Napalpí show that the people adjust their ideas about both what is it to be Qom and what that implies, as well as how an Indigenous territory is shaped by its historical experiences. In Napalpí, these ideas have an effect on the forms of political action taken by Indigenous people, as well as their ideas and expectations about development.

In a context of an economic, environmental, and productive crisis, two elements stand out. On the one hand, political parties' patronage networks, alliances with NGOs, and development projects constitute, in their most pragmatic dimension, a heterogeneous network of channels to distribute benefits through which the Qom attain an important part of their conditions of existence. On the other hand, development projects are pragmatic exchanges that convert their benefits into "things" that, as goods, are negotiated within those networks of benefits. This arrangement, in which development projects are reduced to the political negotiation of their material benefits, is amplified when the State and multilateral organizations transfer the responsibility for constructing development and infrastructure projects to private companies and with it the possibility of enabling mechanisms of social transformation. This 
The International Indigenous Policy Journal, Vol. 10, Iss. 5

mechanism blocks broader and deeper possibilities for political participation, and Indigenous Peoples' rights are far from being incorporated into the practices of private companies and the government: That is to say, they have been incorporated in discourses but not in procedures, techniques, or norms.

Since the State does not have the capacity to give certainty to Indigenous Peoples regarding the quality, efficacy, and security of the infrastructure they install in their territories, Indigenous Peoples are forced to look for third parties that can control the State and the private actors that eventually participate in different stages of works projects in Indigenous territories. Some NGOs try to meet these demands, but they lack the institutional and operational capacity to do it. Thus, we see how a situation emerges in which traditional knowledges are constrained by the use of scientific knowledge to address "technical" challenges. Yet, this scientific knowledge is inadequate in the eyes of Indigenous people trying to confront the potentially negative consequences of infrastructure projects or environmental threats.

In this context, specialized public institutions, like research centers and universities, could do more to provide governments and communities with knowledge that is produced in dialogue with local experiences and knowledges. Practically, when it comes to projects or initiatives linked to common interests or common goods, such as water or action against environmental threats, it is possible and necessary to open spaces for public discussion and political participation through open meetings and/or using local media.

In particular contexts, such as that of the ex-Napalpí reserve, it seems necessary to review the tendency to restrict definitions of Indigenous identity on the basis of preconceptions and idealizations of Indigenous people. These preconceptions tend, as we have seen, to standardize all Indigenous people through preconceived political and administrative bodies (such as associations). The limitations of bodies are evident, not only in the face of the cultural diversity of Indigenous Peoples, but also by the wide diversity of social organizations and traditional economic practices. As we have shown here, the limitations of these figures are also evident in historical terms. Our analysis demonstrates that these preconceived notions also ignore the historical experiences (both of peoples and communities) and the differences in their processes of subjectivity and individual and collective territorialization.

Environmental threats challenge the State, NGOs, Indigenous organizations, and anthropologists not only to act in a different way but also to think on a broader scale and level. In contexts where debates about identity and mutual mistrust threaten to derail projects to address community needs, maps can be used as a tool to mediate between knowledges and to stimulate broader and intercultural conversations about common goods, environmental issues, and history in order to root out patronage modalities and promote a more equal distribution of social development benefits.

Today, the Qom live in paradoxical landscapes and the Colonia case illustrates this situation. For most Indigenous people living on the reserve, the political economy under neoliberal multiculturalism has created an ideal that is impossible for any project to meet because of past historical experiences. Beyond being impossible to satisfy this ideal, it also makes Indigenous Peoples responsible for their failed integration into social structures, for the environmental degradation within their territories, and for the political divisions they continue to face. Based on the experiences of people in Colonia Aborigen, we have seen how they are questioning and refashioning these paradoxical landscapes through their spatial and political practices. In cultural terms, the people's political practices do not show a strict adherence to 
what is considered to be traditional Indigenous cultural values (language, alimentary habits, traditional medicine), but rather seem to prioritize the pursuit of equality with settler populations. In ecological terms, the exploitation of resources, such as water, must sometimes be pragmatically prioritize based on their most urgent economic needs, despite the value attached to traditional knowledge. Finally, in political terms, there are many sets of separate and sometimes opposing units, based on particular interests rather than on a common perspective of shared well-being. We have also seen how the longterm experiences of the inhabitants of Colonia Aborigen Chaco establish a set of practices, representations, and expectations that question the idea that Indigenous people have homogenous ideas about their territories and their identities. Analyzing the contradictory overlaps of several political territories, I affirm that the evidence of these paradoxical landscapes demand we look at the local historical processes in Indigenous territories in order to clarify the diversity of expectations that Indigenous people have about themselves, their realities, and development within their communities.

These issues continue into the present. Recently, seven Wichí children died of malnutrition and a lack of water just west of Chaco region. In examining the children's deaths, Andrés Leake (2020), a researcher in environmental politics, combined two maps. The first showed the locations of the children's communities. The second showed the areas where the forest had been removed, mainly by nonIndigenous landowners and soy producers (approximately 1,235,526 acres over the past 18 years). Based on the maps, Leake concluded the children's deaths were preventable and were the result of the dramatic transformation of the land around their communities and the disruption in the way of life of their people. It is urgent to revised development policies and indicators.

\section{References}

Anderson, T., \& Parker, D. (2008). Sovereignty, credible commitments, and economic prosperity on American Indian Reservations. The Journal of Law \& Economics, 51, 641-666. doi: https://www.doi.org/10.1086/590205

Beck, U. (2007). La sociedad del riesgo: Hacia una nueva modernidad [The risk society: Towards a new modernity]. Barcelona, Spain: Paidós.

Bergholz, M. (2016). Violence as a generative force: Identity, nationalism, and memory in a Balkan community. Ithaca, USA: Cornell University Press.

Biolsi, T. (2005). Imagined geographies: Sovereignty, Indigenous space, and American Indian struggle. American Ethnologist, 32(2), 239-259. doi: https://doi.org/10.1525/ae.2005.32.2.239

Ceriani Cernadas, C., \& Citro, S.(2005). El movimiento del evangelio entre los Toba del Chaco Argentino: Una revision histórica y etnográfica [The gospel movement among the Toba of the Argentine Chaco: A historical and ethnographic review]. In B. Guerrero Jiménez (Ed.), De Indio a Hermano. Pentecostalismo Indígena en América Latina (pp. 111-170). Iquique, Chile: Ediciones El JoteErrante-Campus Universidad Arturo Prat. 
The International Indigenous Policy Journal, Vol. 10, Iss. 5

Constitución de la Nación Argentina, Ley No 24.430, (sancionada en 1853 con las reformas de los años $1860,1866,1898,1957$ y 1994) [Constitution of the Nation of Argentina]. Retrieved from http://servicios.infoleg.gob.ar/infolegInternet/anexos/0-4999/804/norma.htm

Cordeu, E. \& de los Rios, M. (1982). Un enfoque estructural de las variaciones socioculturales de los cazadores-recolectores del Gran Chaco [A structural approach to the sociocultural variations of the hunter-gatherers of the Gran Chaco]. Suplemento Antropológico, 17(1), 131-195.

Dippel, C. (2014). Forced coexistence and economic development: Evidence from Native American reservations. Econometrica, 82(6), 2131-2165. doi: https:www.doi.org/10.3982/ECTA11423

Gordillo, G. (2004). Landscapes of devils: Tensions of place and memory in the Argentinean Chaco. Durham, USA: Duke University Press. doi: https://www.doi.org/10.1215/9780822386025

Government of Argentina. (2010). Informe de cierre préstamos [Loan closing report] (BIRF 4150-AR y 7425-AR). Buenos Aires, Argentina: Secretariat of Agriculture, Livestock, Fishing and Food.

Hodgson, D. (2009). Becoming Indigenous in Africa. African Studies Review, 52(3), 1-32. doi: https:www.doi.org/10.1353/arw.0.0302

Howard-Wagner, D., Bargh, M., \& Altamirano-Jiménez, I. (2018). From new paternalism to new imaginings of possibilities in Australia, Canada and Aotearoa/New Zealand: Indigenous rights and recognition and the State in the neoliberal age. In D. Howard-Wagner, M. Bargh, \& I. Altamirano-Jiménez (Eds.), The neoliberal state, recognition and Indigenous rights (pp. 1-39). Canberra, Australia: ANU Press. doi: https://www.doi.org/10.22459/CAEPR40.07.2018

Instituto Nacional de Estadísticas y Censos (INDEC). (2012). Censo Nacional de población, hogares y viviendas 2010: Censo del Bicentenario [National Census of population, households, and housing 2010: Bicentennial Census]. Buenos Aires, Argentina: Presidencia de la Nación.

Iñigo Carrera, N. (1984). Campañas militares y clase obrera: Chaco 1870-1930 [Milliary campaigns and the working class]. Buenos Aires, Argentina: Centro Editor de América Latina.

Leake, A. (2020, February 18). En zonas de origen de los niños Wichí fallecidos se desmontaron casi medio millón de hectáreas en 18 años [In areas of origin of deceased Wichí children almost half a million hectares were cleared in 18 years]. Pagina 12. Retrieved from https://www.pagina12.com.ar/248166-se-desmontaron-casi-medio-millon-de-hectareas-en-18$\underline{\text { anos }}$

Natenzon, C. \& Ríos, D. (2015). Riesgos, catástrofes y vulnerabilidades: Aportes desde la geografía y otras ciencias sociales para casos Argentinos [Risks, catastrophes and vulnerabilities: Contributions from geography and other social sciences to Argentine cases]. Buenos Aires, Argentina: Imago Mundi.

Peterson, B.(2007). Remains out of place: Race, trauma and nationalism in El Salvador. Anthropological Theory, (1), 59-77. doi: https://doi.org/10.1177/1463499607074293 
Rodríguez, F. (2004). Estudio de impacto ambiental: Proyecto de saneamiento hídrico de la Línea Tapenagá-Diagnóstico socioeconómico y cultural de Colonia Aborigen Chaco, Plan de Desarrollo Indigena [Investigation of environmental effects: Water sanitation project of the Tapenagá Line-Socioeconomic and cultural diagnosis of Colonia Aborigen Chaco, Indigenous Development Plan]. Buenos Aires, Argentina: Programa de Servicios Agrícolas Provinciales (PROSAP).

Rodríguez, F.(2011). Plan de Desarrollo Indígena 2011: Aportes desde PROSAP para la construcción de un desarrollo eco-social con los habitantes de Colonia Aborigen Chaco [Indigenous Development Plan 2011: Contributions from PROSAP for the construction of an eco-social development with the inhabitants of Colonia Aborigen Chaco]. Resistencia, Argentina: Ministerio de la Producción, Provincia del Chaco.

Salamanca, C. (2006). En se glissant dans les fissures de l'utopie: Les Toba aux frontières de l'EtatNation Argentin [Slipping into the cracks of utopia: The Toba at the borders of the Argentine Nation State] (Unpublished doctoral dissertation). École des hautes études en sciences sociales (EHESS), Paris, France.

Salamanca, C. (2009). Os novos Qom: A constituição de uma identidade relacional em devir [The new Qom: The constitution of a relational identity]. Mana, 15(1),155-182. doi: https://www.doi.org/10.1590/S0104-93132009000100006

Salamanca, C. (2010). Revisitando Napalpí: Por una antropología dialógica de la acción social y la violencia [Revisiting Napalpí: An anthropological analysis of social action and violence]. Runa, $31(1), 67-87$.

Salamanca, C. (2015). Políticas de la dictadura militar en una región de frontera. Espacios, tiempos e identidades en el Chaco Argentino [Policies of the military dictatorship in a border region. Spaces, times and identities in the Argentine Chaco]. Revista de Estudios sobre Genocidio, $7(10), 157-176$.

White, J. P., Murphy, L., \& Spence, N. (2012). Water and Indigenous Peoples: Canada's paradox. International Indigenous Policy Journal, 3(3). doi: https://doi.org/10.18584/iipj.2012.3.3.3

World Bank. (2005a). Manual de operaciones del Banco Mundial [World Bank operations manual] (BP 4.10). Retrieved from http://siteresources.worldbank.org/OPSMANUAL/Resources/2103841170795590012/BP4.10.July1.2005.Spanish.pdf

World Bank. (2005b).Politicas operacionales [Operational policies] (OP 4.10). Retrieved from http://siteresources.worldbank.org/OPSMANUAL/Resources/210384-1170795590012/ OP4.10.July1.2005.Spanish.pdf 